\title{
ANALISIS TRANSFARANSI DAN AKUNTABILITAS DANA DESA SEBAGAI PENGUATAN BADAN USAHA MILIK DESA (Studi Badan Usaha Milik Desa Tirta Mandiri Ponggok Klaten)
}

\author{
Pardi $^{1}$, Budi Istiyanto ${ }^{2}$ \\ ${ }^{1}$ Manajemen, Sekolah Tinggi Ilmu Ekonomi Surakarta \\ ${ }^{2}$ Manajemen, Sekolah Tinggi Ilmu Ekonomi Surakarta \\ Jl. Slamet Riyadi Makamhaji 435 - 437 Kartasura Sukoharjo Indonesia \\ Email : se83827@gmail.com
}

\begin{abstract}
This research's objectives are (1) to analyze communities' response on Tirta Mandiri Village-Owned Enterprises (BUMDes)' successful programs, (2) to analyze the transparency of village fund utilization as an empowering effort of BUMDes Tirta Mandiri for village's selfreliance, (3) to analyze the accountability of village fund utilization for village's self-reliance. The qualitative research used Focus Group Discussion, observation, interview, documentation, and physical devices method to collect the data. The data collection process used interview procedures with a self-arranged questionnaire. The data were analyzed using the interactive model which comprises data reduction, data presentation, concluding, and verification followed by the data collection process. The qualitative data were validated using source triangulation. The result of this research shows that (1) there are two kinds of response following the success of BUMDes Tirta Mandiri, they are communities who agree on the programs and the ones who do not, (2) the utilization of village fund as BUMDes Tirta Mandiri's strengthening needs transparency on its process. The utilization of village funds as BUMDes Tirta Mandiri's strengthening on the village's self-reliance needs to be accountable for its accountability report.
\end{abstract}

Keywords: Transparency, Accountability, Village Fund, BUMDes’ Strengthening

\section{PENDAHULUAN}

Otonomi pengelolaan dana desa seharusnya bukan sekedar wujud pertanggungjawaban pengelolaan dana saja, tetapi bagaimana mengelola dana lebih tertuju pada pemberdayaan Usaha Mikro dan Kecil. Filosofi dana desa meningkatkan kesejahteraan dan pemerataan pembangunan desa melalui peningkatan pelayanan publik di desa, memajukan perekonomian desa, mengatasi kesenjangan pembangunan antar desa serta memperkuat masyarakat desa sebagai subjek dari pembangunan (UU. No. 6, 2014).

Prinsip-prinsip pengelolaan Badan Usaha Milik Desa (BUMDes) penting untuk dielaborasi atau diuraikan agar difahami dan dipersepsikan dengan cara yang sama oleh pemerintah desa, anggota (penyerta modal), Badan Permusyawaratan Desa (BPD), Pemerintah kabupaten, dan masyarakat. Terdapat 6 (enam) prinsip dalam mengelola BUMDes yaitu:

a. Kooperatif. Semua komponen yang terlibat di dalam BUMDes harus mampu melakukan kerjasama yang baik demi pengembangan dan kelangsungan hidup usahanya.

b. Partisipatif. Semua komponen yang terlibat di dalam BUMDes harus bersedia secara sukarela atau diminta memberikan dukungan dan kontribusi yang dapat mendorong kemajuan usaha BUMDes.

c. Emansipatif. Semua komponen yang terlibat di dalam BUMDes harus diperlakukan sama tanpa memandang golongan, suku, dan agama. 
d. Transparan. Aktivitas yang berpengaruh terhadap kepentingan masyarakat umum harus dapat diketahui oleh masyarakat dengan mudah dan terbuka.

e. Akuntabel. Seluruh kegiatan usaha harus dapat dipertanggung jawabkan secara teknis maupun administratif.

f. Sustainabel. Kegiatan usaha harus dapat dikembangkan dan dilestarikan oleh masyarakat dalam wadah BUMDes (Permendes. No. 4, 2015, Ps. 4).

Pemerintah, Pemerintah Daerah Provinsi, Pemerintah Daerah Kabupaten atau Kota, dan Pemerintah Desa mendorong perkembangan BUMDesa dengan:

a. memberikan hibah dan atau akses permodalan;

b. melakukan pendampingan teknis dan akses ke pasar; dan

c. memprioritaskan BUM Desa dalam pengelolaan sumber daya alam di Desa (UU. No. 6, 2014: ps.90).

Kapasitas Badan Usaha Milik Desa (BUMDesa) Jolo Sutro Dalam Pengelolaan Potensi Desa Kemiren Glagah Banyuwangi, hasil menunjukan bahwa kapasitas sumber daya manusia dan sumber daya keuangan telah memberikan manfaat bagi desa sesuai tujuan BUMDes, namun pembagian pendapatan bersih berupa kontribusi pendapatan asli desa tidak sesuai dengan AD/ART (Efendi, 2018).

Indonesia memiliki wilayah 33 provinsi dengan jumlah 74.957 desa, tahun 2018 sekitar 41.000 BUMDes telah berdiri, berarti 64 persen desa di Indonesia sudah mempunyai BUMDes. Jumlah BUMDes tersebut belum semuanya berkembang, dan masih perlu mendapat pendampingan agar menjadi pilar ekonomi dan menampung seluruh aktivitas ekonomi yang tumbuh di pedesaan (Kemendes PDTT . https://m.detik.com , 2018).

BUMDes yang memiliki omset terbesar tahun 2017 yaitu; BUMDes Bangun Jaya di Kampar, BUMDes Karang Kandri Sejahtera di Cilacap, BUMDes Mandala Giri Amerta di Buleleng, BUMDes Tirtonirmolo di Bantul, dan BUMDes Tirta Mandiri di Klaten (Kemendesa.go.id).

Salah satu BUMDes yang menarik perhatian pemerintah dan masyarakat adalah BUMDes Tirta Mandiri yang berada di Desa Ponggok, karena tiga tahun berturut-turut sejak 2015 BUMDes mampu mencetak omset terbesar. BUMDes Tirta Mandiri mampu meningkatkan pendapatan setiap tahun, tampak pada Tabel 1.

Tabel 1. Pendapatan BUMDes Tirta Mandiri Ponggok

\begin{tabular}{ccr}
\hline No. & Tahun & Pendapatan (Rp.) \\
\hline 1 & 2014 & 1.153 .075 .730 \\
2 & 2015 & 5.181 .507 .251 \\
3 & 2016 & 10.300 .000 .000 \\
4 & 2017 & 13.452 .670 .412 \\
5 & 2018 & 16.400 .000 .000 \\
\hline
\end{tabular}

Sumber: BUMDes Tirta Mandiri 2020

Penelitian ini bertujuan menganalisis transparansi dan akuntabilitas penyelenggaraan Dana Desa sebagai penguatan BUMDes Tirta Mandiri untuk kemandirian desa. 


\section{PENGERTIAN KEUANGAN DESA}

Paradigma pengelolaan keuangan daerah menuntut lebih besarnya akuntanbilitas dan transparansi dalam pengelolaan keuangan daerah dengan memperhatikan azas keadilan dan kepatutan, dimana masyarakat tidak lagi hanya dipandang sebagai obyek pembangunan tapi sekaligus sebagai subyek pembangunan" (Halim, 2004: 2-3).

Pengertian Keuangan Desa diatur dalam Undang-Undang No.6 Tahun 2014 tentang Desa, ps. (74) sebagai berikut:

a. Belanja Desa diprioritaskan untuk memenuhi kebutuhan pembangunan yang disepakati dalam Musyawarah Desa dan sesuai dengan prioritas Pemerintah Daerah Kabupaten/Kota, Pemerintah Daerah provinsi, dan Pemerintah.

b. Kebutuhan Pembangunan sebagaimana dimaksud pada ayat (1), meliputi, tetapi tidak terbatas pada kebutuhan primer, pelayanan dasar, lingkungan, dan kegiatan pemberdayaan Desa.

Pada bagian kesatu mengenai Keuangan Desa diatur dalam Peraturan Pemerintah Nomor 43 Tahun 2014 tentang pelaksanaan Undang-Undang Nomor 6 tahun 2014 tentang Desa Pasal 93 sebagai berikut:

a. Pengelolaan keuangan Desa meliputi: (a) perencanaan; (b) pelaksanaan; (c) penatausahaan; (d) pelaporan; dan (e) Pertanggung-jawaban.

b. Kepala Desa adalah pemegang kekuasaan pengelolaan keuangan Desa sebagaimana dimaksud pada ayat (1).

c. Dalam melaksanakan kekuasaan pengelolaan keuangan Desa sebagaimana dimaksud pada ayat (2), kepala Desa menguasakan sebagian kekuasaannya kepada perangkat Desa.

Penyaluran Dana Desa dilakukan pemindahbukuan dari Rekening Kas Umum Negara (RKUN) ke Rekening Kas Umum Daerah (RKUD) selanjutnya dilakukan pemindahbukuan dari RKUD ke Rekening Kas Desa (RKD).

Pemindahbukuan Dana Desa dari Rekening Kas Umum Negara (RKUN) ke Rekening Kas Umum Daerah (RKUD) untuk selanjutnya dilakukan pemindahbukuan dari RKUD ke Rekening Kas Desa (RKD) secara bertahap.

Pada bagian kesatu mengenai Keuangan Desa diatur dalam Peraturan Pemerintah Nomor 47 Tahun 2015 atas perubahan Peraturan Pemerintah Nomor 43 tahun 2014, dinyatakan dalam pasal 100 ;

"Belanja Desa yang ditetapkan dalam APB Desa digunakan dengan ketentuan:

a. paling sedikit $70 \%$ (tujuh puluh perseratus) dari jumlah anggaran belanja Desa digunakan untuk mendanai penyelenggaraan Pemerintahan Desa, pelaksanaan pembangunan Desa, pembinaan kemasyarakatan Desa, dan pemberdayaan masyarakat Desa; dan

b. paling banyak 30\% (tiga puluh perseratus) dari jumlah anggaran belanja Desa digunakan untuk:

1) penghasilan tetap dan tunjangan kepala Desa dan perangkat Desa;

2) operasional Pemerintah Desa;

3) tunjangan dan operasional Badan Permusyawaratan Desa; dan

4) insentif rukun tetangga dan rukun warga".

Undang-Undang Desa secara khusus meletakkan dasar bagi perubahan tata kelola desa yang dibangun di atas prinsip keseimbangan antara lembaga (check and balance), demokrasi perwakilan dan permusyawaratan serta proses pengambilan keputusan secara partisipatif melalui musyawarah desa sebagai forum pengambil keputusan tertinggi dalam perencanaan, pelaksanaan, pengawasan dan pertanggungjawaban pembangunan desa.

Tata kelola merupakan sebuah proses interaksi yang melibatkan berbagai bentuk kemitraan, kolaborasi, kompetisi, dan negosiasi. Tata kelola pada dasarnya adalah 
pengambilan keputusan kolektif antar aktor yang berbeda-beda menjadi sangat krusial. Tata kelola yang baik sebagai pendekatan meletakan prinsip-prinsip: partisipasi, akuntanbilitas, dan transparansi (Putera, 2014: 32)

Penggunaan dana desa;

a. Dana Desa digunakan untuk membiayai penyelenggaraan pemerintahan, pembangunan, pemberdayaan masyarakat, dan kemasyarakatan.

b. Penggunaan Dana Desa diprioritaskan untuk pembangunan dan pemberdayaan masyarakat Desa sesuai dengan prioritas penggunaan Dana Desa yang ditetapkan oleh Kementerian Desa, PDT, dan Transmigrasi;

c. Penggunaan Dana Desa untuk kegiatan yang tidak termasuk prioritas dapat dilakukan sepanjang kebutuhan untuk pemenuhan kegiatan pembangunan dan pemberdayaan masyarakat telah terpenuhi;

d. Penggunaan Dana Desa untuk kegiatan yang tidak prioritas harus mendapatkan persetujuan bupati/walikota;

e. Kementerian/lembaga teknis terkait dan kabupaten/kota dapat melakukan pendampingan pelaksanaan Dana Desa.

f. Kepala Desa bertanggung jawab atas penggunaan Dana Desa.

g. Kepala Desa menyampaikan laporan realisasi penggunaan Dana Desa kepada bupati/walikota setiap semester, dengan ketentuan:

1) semester I paling lambat minggu keempat bulan Juli tahun anggaran berjalan; dan

2) semester II paling lambat minggu keempat bulan Januari tahun anggaran berikutnya.

h. Bupati/walikota menyampaikan laporan konsolidasi realisasi penyaluran dan penggunaan Dana Desa kepada Menteri dengan tembusan menteri yang menangani Desa, menteri teknis/pimpinan lembaga pemerintah nonkementerian terkait, dan gubernur paling lambat minggu keempat bulan Maret tahun anggaran berikutnya.

i. Penyampaian laporan konsolidasi realisasi penyaluran dan penggunaan Dana Desa oleh Bupati/Walikota dilakukan setiap tahun.

Monitoring dana desa, Evaluasi;

1) Penghitungan pembagian besaran Dana Desa setiap Desa oleh kabupaten/kota

2) Realisasi penggunaan Dana Desa (Kemenkeu.go.id).

\section{PENGERTIAN BADAN USAHA MILIK DESA}

Badan Usaha Milik Desa, selanjutya disebut BUM Desa, adalah badan usaha yang seluruh atau sebagian besar modalnya dimiliki oleh Desa melalui penyertaan secara langsung yang berasal dari kekayaan Desa yang dipisahkan guna mengelola aset, jasa pelayanan dan usaha lainnya untuk sebesar-besarnya kesejahteraan masyarakat Desa (UU No.6, 2014: ps1 ayat 6).

\section{Peranan BUMDes.}

BUM Desa diposisikan sebagai salah satu kebijakan pemerintah untuk mewujudkan Nawa Cita Pertama, Ketiga, Kelima dan Ketujuh, dengan pemaknaan sebagai berikut:

a. BUM Desa merupakan salah satu strategi kebijakan menghadirkan institusi negara (Kementerian Desa PDTT) dalam kehidupan bermasyarakat dan bernegara di Desa ( Tradisi Berdesa).

b. BUM Desa merupakan salah satu strategi kebijakan membangun Indonesia dari pinggiran melalui pengembangan usaha ekonomi Desa yang bersifat kolektif.

c. BUM Desa merupakan salah satu strategi kebijakan pemerintah untuk meningkatkan kualitas hidup manusia Indonesia di Desa. 
d. BUM Desa merupakan salah satu bentuk kemandirian ekonomi Desa dengan menggerakkan unit-unit usaha strategis bagi usaha ekonomi kolektif Desa (Putra, 2015: 9).

\section{KERANGKA BERPIKIR}

Penulis menganalisis penyelenggaraan dana desa untuk kemadirian BUMDes yang meliputi: (1) Sikap Masyarakat; (2) Transparansi; (3) Akuntabilitas. Kerangka berpikir dari penelitian ini dapat disampaikan pada Gambar 1.

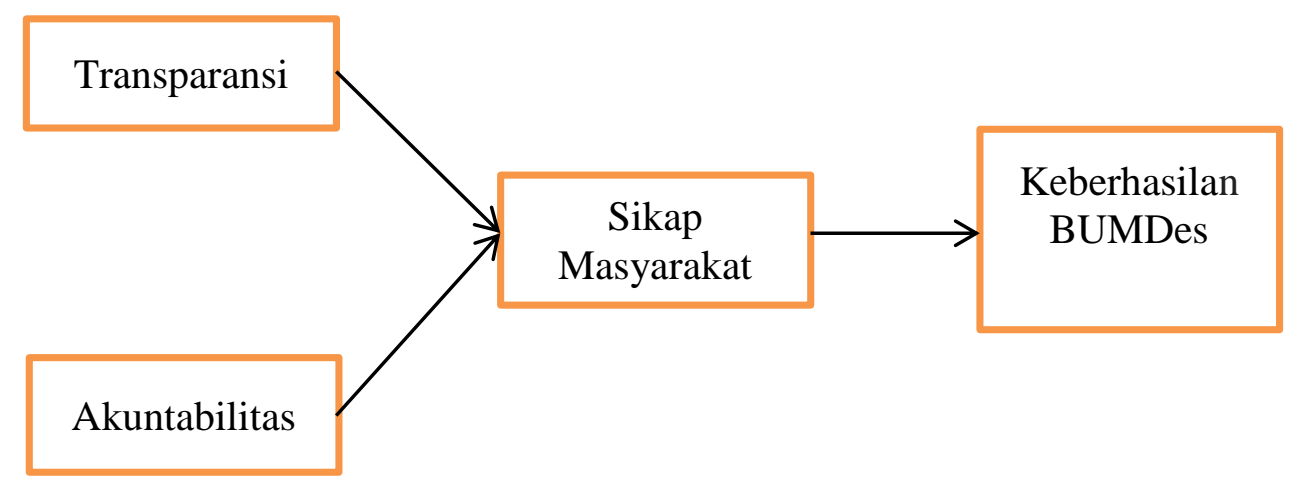

\section{Dimensi Penelitian}

Gambar 1. Kerangka Berpikir Penelitian

Dimensi penelitian kualitatif pada dasarnya merupakan penjelasan tentang informasi yang akan dikumpulkan untuk setiap variabel penelitian. (Mardikanto, 2012: 142). Dimensidimensi penelitian tersebut di atas dijelaskan berikut;

\section{- Sikap Masyarakat}

Dalam penelitian ini untuk mengukur sikap menggunakan dimensi dari metode fishbein. Model fishbein merupakan metode yang didasarkan pemikiran bahwa sikap dibentuk komponen kepercayaan (beliefs) dan perasaan (feeling) masyarakat. Sikap masyarakat dapat dilihat dari tingkah kepercayaan masyarakat desa terhadap keberhasilan BUMDes Tirta Mandiri terkait penyeleggaraan dana desa.

\section{- Transparansi}

Transparansi dapat dijelaskan semua aktivitas dengan prinsip keterbukaan yang memungkinkan masyarakat untuk mengetahui dan mendapatkan akses seluas-luasnya (tidak boleh satupun yang ditutupi) dalam penyelenggaraan dana desa sebagai penguatan BUMDes.

\section{- Akuntabilitas}

Akuntabilitas dijelaskan sebagai pertanggungjawaban sesuai dengan peraturan dan perundangan-undangan yang berlaku tentang pengelolaan, pengendalian, dan penyelenggaraan dana desa.

\section{- Keberhasilan BUMDes}

BUMDes adalah Badan Usaha Milik Desa Tirta Mandiri yang dibentuk berdasarkan teknis pelaksanaan peraturan dan unsur masyarakat desa Ponggok Polanharjo Klaten bertujuan peningkatan ekonomi desa dan bisnis komersil dengan tatakelola yang baik berdasarkan kemampuan sumber daya dengan dukungan alokasi dana desa. Berikut ini merupakan dimensi keberhasilan BUMDes: (1) Kemandirian BUMDes Tirta Mandiri; (2) Kemandirian Masyarakat desa; (3) Kemandirian Desa. 


\section{METODE PENELITIAN}

a. Tempat Penelitian

Penelitian ini dilaksanakan pada BUMDes Tirta Mandiri, masyarakat, dan pemerintah desa Ponggok Polanharjo Klaten, dengan alasan (2) BUMDes tersebut mampu mengembangkan usaha-usaha dan menggerakkan ekonomi desa serta kegiatan sosial masyarakat.

b. Jenis Penelitian

Pandangan dunia filosofis, ada empat jenis penelitian yaitu: post-positivisme, konstruktivisme, advokasi/partisipatoris, dan pragmatisme (Creswell, 2014: 8). Peneliti ini menggunakan pandangan partisipatoris yaitu penelitian yang memiliki aksi reformasi partisipan dan intitusi.

Penelitian ini termasuk jenis penelitian kualitatif yang bermaksud mengetahui fenomena ekonomi dan sosial mengenai BUMDes sebagai model kelembagaan ekonomi yang melibatkan partisipasi masyarakat desa.

c. Data dan Sumber Data

Data adalah dalam bentuk kata-kata, termasuk kutipan-kutipan atau diskripsi peristiwa-peristiwa khusus (Ahmadi, 2014: ). Data dalam penelitian ini adalah berupa kutipan dan rekaman wawancara, arsip BUMdes Tirta Mandiri, arsip pemerintah desa ponggok, dokumen (foto) aktivitas/kegiatan pemberdayaan dan dokumen usaha masyarakat.

Sumber data dalam penelitian ini, yaitu; Narasumber (Informan) Pelaku penelitian adalah sumber data dan informasi yang disebut informan. Informan kunci adalah orang yang menjadi juru bahasa atau pemberi informasi pertama dan mendasar mengenai masyarakat dan kebudayaan yang diteliti, dan sebagai orang yang dapat memperkenalkan peneliti kepada masyarakat. Setiap pemberi informasi dalam penelitian kualitatif adalah informan (Patilima, 2013: 85). Pemilihan informan dalam penelitian ini didasarkan pertimbangan aktif di lingkungan warga, berkemampuan dalam mengemukakan pendapat, mampu menggambarkan serta bersedia terlibat dalam penelitian langsung. Beberapa informan dalam ini penelitian yaitu;

1) Kepala Desa Ponggok Polanharjo Klaten

2) Sekretaris Desa Ponggok Polanharjo Klaten.

3) Badan Permusyawaratan Desa (BPD).

4) Direktur BUMDes Tirta Mandiri.

5) Ketua Kelompok Sadar Wisata (Pokdarwis) Manua Tirta Ponggok

6) Warga desa Ponggok Polanharjo Klaten

Data dan Sumber Data yang diperlukan tampak tabel 2; 
Tabel 2. Data dan Sumber Data Yang Diperlukan

\begin{tabular}{|c|c|c|c|c|}
\hline No & $\begin{array}{l}\text { Permasalahan } \\
\text { Penelitian }\end{array}$ & Data Yang Dibutuhkan & Sifat Data & Sumber Data \\
\hline 1. & Sikap Masyarakat & $\begin{array}{l}\text { Manfaat yang diterima } \\
\text { masyarakat dari program } \\
\text { BUMDes }\end{array}$ & Kualitatif & $\begin{array}{l}\text { Masyarakat; } \\
\text { BUMDes; } \\
\text { Pemerintah } \\
\text { Desa }\end{array}$ \\
\hline 2 & $\begin{array}{l}\text { Transparansi } \\
\text { Penyelenggaraan } \\
\text { dana desa }\end{array}$ & $\begin{array}{l}\text { Masyarakat mengetahui } \\
\text { dan mendapatkan akses } \\
\text { penyelenggaraan dana } \\
\text { desa. }\end{array}$ & Kualitatif & $\begin{array}{l}\text { Masyarakat; } \\
\text { BUMDes; } \\
\text { Pemerintahan } \\
\text { Desa }\end{array}$ \\
\hline 3 & $\begin{array}{l}\text { Akuntabilitas } \\
\text { Penyelenggaraan } \\
\text { dana desa }\end{array}$ & $\begin{array}{l}\text { Masyarakat mendapat } \\
\text { laporan } \\
\text { Pertanggungjawaban } \\
\text { pengelolaan dana desa }\end{array}$ & Kualitatif & $\begin{array}{l}\text { Masyarakat; } \\
\text { BUMDes; } \\
\text { Pemerintahan } \\
\text { Desa }\end{array}$ \\
\hline 4 & $\begin{array}{l}\text { Keberhasilan } \\
\text { BUMDes }\end{array}$ & $\begin{array}{l}\text { - Kemandirian BUMDes } \\
\text { - Kemandirian } \\
\text { Masyarakat } \\
\text { - Kemandirian Desa }\end{array}$ & Kualitatif & $\begin{array}{l}\text { Masyarakat; } \\
\text { BUMDes; } \\
\text { Pemerintah } \\
\text { Desa }\end{array}$ \\
\hline
\end{tabular}

Sumber: Dokumen Peneliti 2020

d. Teknik Pengumpulan Data

Teknik pengumpulan data merupakan langkah yang paling strategis dalam penelitian, karena tujuan utama dari penelitian adalah mendapatkan data. Tanpa mengetahui teknik pengumpulan data, maka peneliti tidak akan mendapatkan data yang memenuhi standar data yang ditetapkan. Teknik pengumpulan data dilakukan dengan observasi (pengamatan), interview (wawancara), kuesioner (angket), dokumentasi dan gabungan/triangulasi (Sugiyono, 2013: 62). Teknik pengumpulan data yang digunakan dalam penelitian ini adalah teknik gabungan atau triangulasi yaitu triangulasi sumber. Penelitian kualitatif menggunakan pendekatan merekam data penelitian. Peneliti menggunakan metode pengumpulan data untuk merekam data penelitian dengan prosedur berikut; (1) Focus Group Discussion; (2) Observasi; (3) Wawancara; (4) Dokumentasi; (5) Perangkat Fisik;

e. Teknik Analisis Data

1) Analisis Data Kualitatif

Analisis data dalam penelitian kualitatif, dilakukan pada saat pengumpulan data, dan setelah selesai pengumpulan data dalam periode tertentu. Pada saat wawancara peneliti sudah melakukan analisis terhadap jawaban yang diwawancarai. Bila jawaban yang diwawancarai setelah dianalisis belum memuaskan, maka peneliti akan melanjutkan pertanyaan lagi, sampai tahap tertetntu, diperoleh data yang dianggap kredibel (Sugiyono, 2013: 91). Teknik analisa data yang dilakukan dalam penelitian ini adalah teknik analisa data model interaktif yang meliputi reduksi data, sajian data dan penarikan simpulan serta verifikasi yang diikuti proses pengumpulan data.

2) Reliabilitas Data Dan Validitas Data

a) Reliabilitas Data

Reliabelitas kualitatif mengindikasikan pendekatan yang digunakan peneliti secara konsisten jika diterapkan oleh peneliti lain dan untuk penelitian yang berbeda. Prosedur reliabelitas berikut: 
- Mengecek hasil transkripsi untuk memastikan tidak adanya kesalahan yang dibuat selama proses transkripsi.

- Memastikan tidak ada definisi dan makna yang mengambang mengenai kodekode selama proses coding. Hal ini dapat dilakukan dengan terus membandingkan data dengan kode-kode/catatan kode dan definisinya.

- Penelitian berbentuk tim, mendikusikan kode-kode bersama partner satu tim dalam sharing analisis.

- Melakukan cross-ceck dan membandingkan kode-kode yang dibuat oleh peneliti lain dengan kode-kode yang telah dibuat sendiri (Creswell, 2014: 285).

b) Validitas Data

Validitas kualitatif merupakan upaya pemeriksaan terhadap akurasi hasil penelitian dengan menerapkan prosedur-prosedur tertentu. Validitas data dalam penelitian kualitatif dilakukan dengan teknik triangulasi. Triangulasi dalam pengujian kredibilitas ini diartikan sebagai pengecekan data dari berbagai sumber dengan berbagai cara dan berbagai waktu (Sugiyono, 2013: 125). Triangulasi sumber untuk menguji kredibilitas data dilakukan dengan cara mengecek data yang telah diperoleh melalui beberapa sumber. Data yang telah dianalisis oleh peneliti sehingga menghasilkan suatu kesimpulan selanjutnya dimintakan kesepakatan (member chcek) dengan tiga sumber data (Sugiyono, 2013: 127). Peneliti menggunakan triangulasi sumber data untuk menguji kecocokan data terkait pengembangan kelembagaan BUMDes melalui pemberdayaan masyarakat yang diperoleh melalui beberapa sumber untuk memastikan data yang diperoleh cocok/benar. Triangulasi sumber data dapat dilihat Gambar 3.3, berikut:

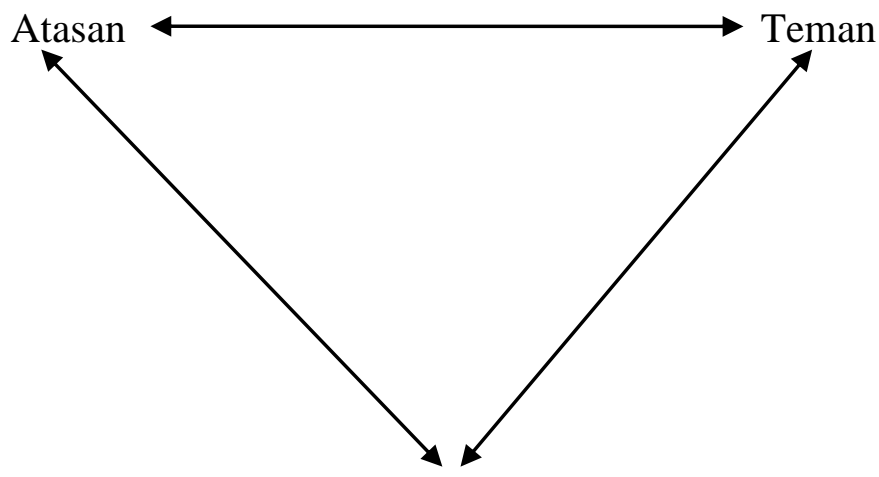

Bawahan

Gambar. 3.3. Triangulasi Sumber Data

Sumber: Sugiyono (2013: 127)

\section{HASIL PENELITIAN}

\section{- Sikap Masyarakat}

Program BUMDes Tirta Mandiri adalah program yang dibuat dan disepakati oleh warga masyarakat, tokoh masyarakat serta pemerintah desa ponggok. Pemerintah desa telah melakukan segala persiapan dan sosialisasi terhadap seluruh program BUMDes seperti yang dikatakan narasumber/informan dalam wawancara berikut ini:

"Pemeritah desa bersama BPD dan tokoh masyarakat melakukan proses sosialisasi dan pelembagaan BUMDes secara partisipatif kelompok masyarakat dan bermusyawarah. Pada awal mulai sosialisasi BUMDes kepada masyarakat bekerjasama dengan pihak pendamping desa dari pihak luar yang memiliki kompetensi."

(Hasil Wawancara dengan Informan Pemerintah Desa Ponggok) 
Dalam keberhasilan tersebut terdapat dua sikap masyarakat yang setuju dan tidak setuju terhadap program-program BUMDes. Pertentangan sebagai akibat BUMDes Tirta Mandiri sudah dianggap tidak berpihak masyarakat kecil mengabaikan nilai sosial dan berorientasi laba/profit. Berikut ini digambarkan pertentangan warga masyarakat desa Ponggok;

a. Masyarakat Yang Setuju program BUMDes Tirta Mandiri

Melalui sosialisasi yang dilakukan BUMDes berdampak pada sikap masyarakat setuju program BUMDes, mempunyai alasan bahwa BUMDes bermanfaat bagi masyarakat, hasil wawancara dengan informan berikut ini:

"Karena banyak keuntungan. Di sini jika tidak mampu anak dibiayai, janda-janda dipelihara. Anak sekolah yang berhasil mendapat ranking 1, 2, 3 mendapat hadiah dari desa $R p$ 200.000. Cucu saya dahulu juga dibiayai sampai SMA. $R W$ di sini dapat menyewakan kursi dan toilet untuk kemudian masuk ke penghasilan $R W$, lahan parkir dibagi-bagi per bulan. Jika dari SD anak tidak mampu sekolah kemudian dibiayai hingga kuliah, jika ada orang sakit tidak mampu merupakan tanggungjawab desa."

(Hasil Wawancara dengan Informan Warga Desa Ponggok)

Manfaat BUMDes bagi masyarakat desa dapat diketahui hasil wawancara dengan informan PT. Ponggok Ciblon, berikut ini;

"Pemberdayaan masyarakat telah dilakukan dengan merekrut pegawai yang dipekerjaan merupakan warga Desa Ponggok. Fasilitas yang diterima berupa gaji sebesar upah minimal regional (UMR) Kota Klaten ditambah tunjangan berupa; uang makan, transportasi dan layanan kesehatan”.

(Hasil Wawancara dengan Informan PT. Ponggok Ciblon)

Manfaat BUMDes bagi pemerintah Desa Ponggok dapat diketahui wawancara informan Pemerintah Desa Ponggok berikut;

"pada awalnya berdiri BUMDes belum dapat memberi manfaat ke pemerintah desa karena pendapatannya rendah, tapi proses perjalanan waktu mulai tahun 2015 dan sampai sekarang Pendapatan Kas Desa (PAD) pemerintah desa ponggok diperoleh dari BUMDes dua milyar lebih setiap tahun sehingga pemerintah desa bisa melaksanakan pembangunan dan mensejahterakan masyarakat secara mandiri tanpa tergantung dana pemerintah kabupaten"

(Hasil Wawancara dengan Informan Pemerintah Desa Ponggok)

b. Masyarakat Yang Tidak Setuju program BUMDes Tirta Mandiri

Adanya industri pariwisata ponggok membawa dampak terjadinya pola pikir masyarakat yang semakin rasionalis yaitu segala sesuatu ditentukan apa yang didapat. Menurut narasumber (Informan) pengurus Pokdarwis Desa Ponggok menceritakan;

"Kegiatan pokdarwis Manua Tirta ponggok dibentuk berdasarkan Peraturan desa Ponggok mempunyai kegiatan menghidupkan dan memajukan kepariwisataan yang mempunyai nilai manfaat bagi kesejahteraan masyarakat dan menciptakan akses bagi usaha kecil menjadi bagian mata rantai kepariwisataan”

Selain itu kegiatan tersebut kelompok sadar wisata (Pokdarwis) Manua Tirta Ponggok juga mempunyai keekonomian, seperti hasil wawancara dengan informan:

"Kami mengelola sumber daya alam lainnya seperti pisang yang diolah kemudian dijual, kemudian dari pemandu wisata yang berasal dari teman-teman POKDARWIS kan bisa menciptakan lapangan pekerjaan”.

(Hasil Wawancara dengan Informan Pengurus Pokdarwis) 
Menurut informan pengelola Pokdarwis mengatakan; "pokdarwis sebagai kelembagaan ekonomi baru di masyarakat yang mempunyai peran menetapkan aturan yang disepakati bersama untuk meningkatkan pendapatan ekonomi masyarakat".

Keberadaan BUMDes tidak dapat menyentuh langsung ke warganya, seperti yang dikatakan informan berikut :

"Ini intinya kan bisa menyasar ke warga langsung, jika BUMDes dia kan hanya mentarget ke PAD desa, PAD desa otomatis nanti kan ke desa. Trus apa nanti ke masyarakat? Karyawan pun banyak yang orang luar. Lalu untuk saham, katakanlah setiap orang Rp 5.000.000:- itu dapat Rp 100.000:- gak seberapa. Tapi bayangkan dengan POKDARWIS yang kami dapat mengakomodir langsung ke bawah, saya bisa mempekerjakan teman-teman dan ibu-ibu yang sudah tua-tua, jadi tidak kemanamana."

(Hasil Wawancara dengan Informan Pengurus Pokdarwis)

\section{- Transparansi dan Akuntabilitas}

"Akuntabilitas manajerial (performance accountability), merupakan pertanggungjawaban untuk pengelolaan organisasi secara efektif dan efisien, seperti yang nampak pada hasil wawancara sebagai berikut:

"Saya bertanggungjawab mengawasi serta menyetorkan laporan yang telah dibuat oleh sekretaris kepada Kepala Desa tiap bulannya".

(Hasil Wawancara dengan Informan PT. Ponggok Ciblon)

Transparansi dan akuntabilitas BUMDes Tirta Mandiri diwujudkan melalui sistem pelaporan dan administrasi pendukung yang sederhana kepada masyarakat Desa Ponggok. Terkait transparansi dan akuntabilitas masih tahap penyempurnaan, seperti yang disampaikan informan:

"Gini, saya berbicara proses ya Pak, Ponggok itu besar tidak langsung besar seperti ini bahkan dalam hal profesionalisme, transparan dan akuntabel. Dari tahun ke tahun kami ini bertahap, bahkan tahun ini pun standar akuntansi yang kami pakai adalah SAK ETAP yang mendekati lah dengan pengelolaan di BUMDes karena dengan koperasi ya jauh padahal di belakangnya kami juga cukup besar di holding. Nah gimana caranya untuk transparansi tentunya yang namanya transparan gak harus njlimet (secara detail) tetapi ada hal-hal yang kita patuhi kenapa ada standar akuntansi supaya kinerja keuangan kami bisa dipotret apakah ini bener, salah, baik, buruk, profit atau defisit dan sebagainya. Nah untuk menjaga akuntabilitas dan transparan ini tentunya perlu kita open untuk menjaga trush masyarakat kepada BUMDes. Nah untuk kedepannya sudah mulai online Pak, jadi akses pelaporan kami sudah dibaca oleh masyarakat, tentunya apa yang kita tampilkan adalah neraca, laba rugi, perubahan modal dan tentunya cash bon-nya atau arus kasnya supaya bisa diketahui oleh masyarakat. Di satu sisi orang di luar Ponggok yang masih bingung sebenarnya standar laporan keuangan seperti apa sih, nah itu juga memberi edukasi ke luar. Ini kalau menurut saya pribadi itu yang dilakukan oleh Ponggok karena nuwun sewu (mohon maaf) dari kementrian desa sendiri belum memberikan wadah yang bareng-bareng 'ayo iki lagi bingung digawe regulasi BUMDes, BUMDes ngene' nah begitu ada omsetnya itu standar apa yang dipakai karena dari ujung pangkalnya tidak ditentukan jadi kita di bawah ini golek-golek sing pas, aplikasi keuanganlah dan sebagainya".

(Hasil Wawancara dengan Informan BUMDes Tirta Mandiri) 
Dalam wawancara peneliti dengan informan lain menyatakan bahwa sebelum tahun 2018 BUMDes tidak memiliki standar akuntansi atau pelaporan penggunaan dana desa yang jelas.

"Bagaimana kiranya BUMDes memiliki suatu akuntansi yang diakui sesuai standar layaknya, atau bahkan diakui negara. Maka, BPD juga menyarankan silakan mencari pendamping atau lembaga yang akan membimbing membuatkan sistem akuntansi managemen dan keuangan, maka menjalin kerjasama dengan staf ahli akuntansi dari STAN. Harapannya akan memberikan; pendampingan, peningkatan kapasitas SDM di BUMDes terutama bidang akuntansi managemen dan keuangan. Maka di tahun anggaran 2018 BUMDes sepakat membuat akuntansi keuangan dan aplikasinya yang diakui oleh negara yaitu SAK ETAP. Semua lembaga yang ada di desa yang mengakses bahwa sistem itu yang harus dipakai dan ditaati oleh lembaga desa. Nah kalau keuangannya tentu BPD memiliki kewenangan terhadap kepastian hukum terhadap pelaporan keuangan atau kegiatan yang dilakukan BUMDes. Maka harapannya tata kelola keuangan di managemen BUMDes itu perhari harus dilakukan secara update karena BUMDes ini mengelola potensi yang mempunyai seratus sistem dadakan dan juga melakukan pembiayaan jadi harapannya setiap hari harus muncul, melakukan pemasukan berapa, pembiayaan berapa dan saldo atau laba itu berapa, kalau laba berapa kalau rugi berapa. Maka dari percepatan akumulasi akhir bulan akan lebih cepat".

(Hasil Wawancara dengan Informan BPD)

\section{ANALISIS PEMBAHASAN}

\section{Sikap Masyarakat}

a. Masyarakat setuju program BUMDes, mempunyai alasan bahwa BUMDes bermanfaat bagi masyarakat karena ada: biaya pendidikan, jaminan kesehatan, pendapatan warga dari usaha warung, usaha lainnya. Selain manfaat tersebut BUMDes juga bermanfaat bagi karyawan, karena dapat menampung tenaga kerja dengan gaji UMR ditambah tunjangan uang makan, transportasi, dan kesehatan.

a. Sikap masyarakat yang kurang atau tidak setuju program BUMDes, dengan alasan BUMDes yang dianggap tidak berpihak masyarakat kecil mengabaikan nilai sosial dan hanya berorientasi pada laba/profit, yang mendapat kesejahteraan pimpinan sementara fungsi mengkoordinasi bawahan belum baik.

\section{Transparansi dan Akuntabilitas}

Penyerahan kewenangan serta tanggungjawab dari pemerintah pusat kepada pemerintah daerah otonom harus disertai dengan sistem atau strategi yang mampu mengatur dan mengawasi pengelolaan dana dengan baik sehingga terwujud sebuah sistem yang terpercaya, akuntabel, transparan, dan dapat dipertanggungjawabkan. Tata kelola keuangan daerah harus mencakup secara keseluruhan dari peraturan, kelembagaan, sistem informasi keuangan, maupun kontrol terhadap kualitas sumber daya manusia" (Yuliani dkk, 2010). Berdasarkan penjelasan tersebut yang dimaksud transparansi dalam penelitian ini; (1) adanya keterbukaan informasi mudah dipahami oleh masyarakat. (2) adanya publikasi detail mengenai pengelolaan anggaran pendapatan dan belanja desa. Sedangkan yang dimaksud akuntabilitas adalah pertanggungjawaban hukum, kinerja, program, kebijakan dan pengelolaan APBDes.

Transparansi dan akuntabilitas yang telah dilaksanakan BUMDes Tirta Mandiri masih dalam tahap penyempurnaan, dalam hal transparansi dan akuntabilitas dilaksanakan 
secara bertahap, seperti penerapan sistem akuntansi berbasis SAK ETAP. BUMDes Tirta Mandiri sudah merangcang sistem pelaporan online yang dapat dibaca masyarakat (neraca, laba rugi, perubahan modal dan arus kas). Tahun anggaran 2018 BUMDes sepakat membuat akuntansi keuangan dan aplikasinya yang diakui oleh negara yaitu SAK ETAP. Semua lembaga yang ada di desa yang mengakses bahwa sistem itu yang harus dipakai dan ditaati oleh lembaga desa.

Berdasarkan pembahasan tersebut diatas transparansi yang baik dapat dilihat melalui beberapa indikator yaitu kesediaan dan aksesbilitas dokumen, kejelasan dan kelengkapan informasi, keterbukaan proses dan kerangka regulasi menjamin transparansi. Transparansi mengisyaratkan bahwa akuntabilitas laporan pertanggungjawaban tidak hanya dibuat/dilaporkan, namun juga bersifat terbuka dan mudah diakses masyarakat. Oleh karena itu, terjadi proses saling mengawasi guna meminimalisir penyalahgunaan anggaran. Prinsip transparansi menciptakan hubungan timbal balik antara pemerintah desa dengan masyarakat sehingga ada kepercayaan.

Keberhasilan BUMDes yang didukung transparansi dan akuntabilitas penyelenggaraan dana desa dengan pertimbangan sebagai berikut:

a. Mempertimbangkan dan mengesahkan setiap usaha dalam BUMDes Tirta Mandiri menjadi PT untuk meminimalisir kepentingan tertentu (politik) sehingga dapat terjadi keberlangsungan usaha.

b. Berdasarkan AD/ART serta regulasi yang ada dalam pelaksanaannya BUMDes membutuhkan badan pengawas.

c. Masyarakat sekaligus menjadi pengawas dari pelaksanaan BUMDes.

d. Standar akuntansi yang digunakan untuk BUMDes secara nasional.

\section{SIMPULAN}

\section{Sikap Masyarakat}

Keberhasilan Badan Usaha Milik Desa Tirta Mandiri melalui pemberdayaan masyarakat mempunyai dampak kepada masyarakat, sehingga berpengaruh terhadap sikap masyarakat. Sikap masyarakat yang setuju program BUMDes dapat diketahui dari keikutsertaan masyarakat terhadap program BUMDes Tirta Mandiri, salah satunya melalui investasi saham dangan mendapat penghasilan setiap bulan. Sikap masyarakat yang kurang atau tidak setuju nampak dari munculnya unit-unit usaha yang tidak tergabung dalam BUMDes Tirta Mandiri.

\section{Transparansi}

Transparansi yang baik dapat dilihat melalui beberapa indikator yaitu: kesediaan dan aksebilitas dokumen, kejelasan dan kelengkapan informasi, keterbukaan proses dan kerangka regulasi yang menjamin transparasi. Transparansi penyelenggaraan dana desa dalam penguatan BUMDes Tirta Mandiri mencakup kesediaan dan aksebilitas dokumen namun belum mencakup tiga indikator lainnya.

\section{Akuntabilitas}

Akuntabilitas atau laporan pertanggungjawaban tidak hanya dibuat mengisyaratkan bahwa transparansi saja, namun bersifat terbuka dan memudahkan akses masyarakat sehingga terjadi proses saling mengawasi sehingga dapat meminimalisir penyalahgunaan anggaran. Prinsip transparansi menciptakan hubungan timbal balik antara pemerintah desa dengan masyarakat sehingga menciptakan kepercayaan.

\section{Keberhasilan BUMDes}

Keberhasilan BUMDes Tirta Mandiri karena didukung sikap masyarakat yang positif terhadap program BUMDes, hal tersebut karena adanya transparansi dan akuntabilitas 
penyelenggaraan. Keberhasilan BUMDes Tirta Mandiri mampu mewujudkan kemandirian desa dalam keberlanjutan pembangunan dan kesejahteraan masyarakat.

\section{IMPLIKASI}

Badan Usaha Milik Desa berperan untuk kemandirian desa sebagai penguatan dana desa melalui bagian sisa hasil usaha yang disetor ke Pendapatan Kas Desa (PAD). Masyarakat desa bersikap setuju aktif terhadap pengelolaan dana desa yang sebagian besar berorientasi pada pembangunan inprastruktur/pisik sebagai penguatan pengembangan kegiatan Badan Usaha Milik Desa. Sikap masyarakat yang partisipatif melalui keterlibatan musyawarah desa, pengawasan pelaksanaan pembangunan pisik dan pengawasan anggaran dalam bentuk transparansi anggaran pendapatan dan belanja desa (APBDes).

\section{DAFTAR PUSTAKA}

Ahmadi, Ruslam. 2014. Metodologi Penelitian Kualitatif. Ar-Ruzz Media. Jakarta.

BUMDes Tirta Mandiri. 2019. Pengelolaan Dan Perencanaan Usaha Bumdes Tirta Mandiri. Ponggok Klaten.

Creswell, John W. 2014. Research Design, Terjemahan Edisi Ketiga. Pustaka Pelajar. Yogyakarta.

Efendi, Moch Irfan. 2018. Kapasitas Badan Usaha Milik Desa Jolo Sutro Dalam Pengelolaan Potensi Desa Di Desa Kemiren Kecamatan Glagah Kabupaten Banyuwangi. Universitas Jember. Banyuwangi

Halim, Abdul. 2004. Manajemen Keuangan Daerah. AMP YKPN. Yogyakarta.

Kemendes PDTT. 2018. https://m.detik.com/finance/berita-ekonomi-bisnis/d-4318416/ri-punya41000-bumdes-tersebar-di-74957-desa

Mardikanto, Totok. 2012, Metode Penelitian Dan Evaluasi Pemberdayaan Masyarakat, Surakarta, UNS

Patilima, Hamid. 2013. Metode Penelitian Kualitatif Edisi Revisi. Alfabeta. Bandung.

Peraturan Pemerintah Nomor 43 Tahun 2014 Tentang Pelaksanaan Keuangan Desa.

Peraturan Pemerintah Nomor 47 Tahun 2015 Tentang Perubahan Peraturan Pemerintah Nomor 43 Tahun 2014.

Peraturan Menteri Desa PDTT Nomor 4 Tahun 2015 Tentang Pendirian Pengurusan, dan Pengelolaan, dan Pembubaran Badan Usaha Milik Desa.

Putera, Prakoso Bhairawa. 2014. Tata Kelola Sistem Inovasi Nasional di Indonesia. LIPI Press, Jakarta.

Sugiyono. 2013. Memahami Penelitian Kualitatif. ALFABETA. CV. Bandung.

Undang Undang Nomor 6 Tahun 2014 Tentang Desa. 